\title{
CUSTOMER PURCHASE INTENTIONS TOWARD ISLAMIC BANKING PRODUCTS IN PAKISTAN: A STUDY OF RELIGIOSITY-BASED MARKETING
}

(D) Mirza Ashfaq
Ahmed ${ }^{++}$
(i) Riffat Zulfiqar ${ }^{2}$
(D) Muhammad Anwar
ul Haq $^{3}$
(D) Noreena Kausar
(i) Shaista Khalid

Article History Revised: 12 September 2020 Accepted: 5 October 2020 Published: 19 October 2020

\section{Keywords}

Islamic banking products Religiosity-based marketing Credibility

WoM

Customer relationship

Religiosity

Purchase intention.

JEL Classification: G20, G21, M31.

\author{
${ }^{1,3}$ Assistant Professor, Department of Management Sciences, University of \\ Gujrat, Pakistan. \\ 'Email: ashfaq.ahmed@uog.edu.pk Tel: +923s343s6616 \\ sEmail: anwar.haq@uog.edu.pk Tel:923s34818352 \\ ${ }^{\circ}$ MS Scholar, Department of Management Sciences, University of Gujrat, \\ Pakistan. \\ 'Email: rifatz786@gmail.com Tel: +923314725149 \\ "Assistant Professor, Department of Psychology, University of Gujrat, \\ Pakistan. \\ ${ }^{4}$ Email:noreena.kausar@uog.edu.pk.Tel:923316278295 \\ ${ }^{5}$ Assistant Professor, Department of Education, University of Sargodha, \\ Pakistan. \\ ${ }^{5}$ Email: shaista.khalid@uos.edu.pk.Tel:923344220838
}

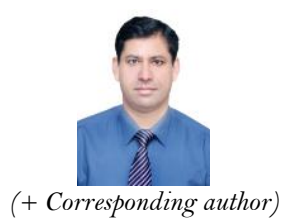

(+ Corresponding author)

\section{ABSTRACT}

This study evaluates the contribution of religiosity-based marketing to persuade customers to purchase Islamic banking products through credibility, word of mouth and building customer relationships. An adapted survey questionnaire was used to collect the data from 440 respondents through convenience sampling from Gujranwala Division, Pakistan. Structural relations were assessed by employing the PLS-SEM (partial least squares structural equation modeling) technique, and the results revealed the existence of a positive and significant relationship between religiosity-based marketing and the purchase intentions of customers. However, credibility does not contribute to purchase intentions, possibly because the credibility of commercial banks is yet to be established in Pakistan. Religiosity-based marketing has been tested for the first time to evaluate its effectiveness in influencing the purchase behavior of Pakistani customers of Islamic banking products. Furthermore, the attempt to validate the conceptual model by using responses from a Muslim country shows its potential to be replicated in other Muslim countries.

Contribution/Originality: This study contributes to existing literature by assessing the role of religiositybased marketing in turning the purchase intentions of consumers toward Islamic financial products. Marketing strategies designed in line with these recommendations will help banks to maintain and improve their customer base through credible offerings, generating positive word of mouth and strengthening relationships with customers.

\section{INTRODUCTION}

Term "religiosity" is derived from the word "religion" and is defined as basic belief or faith. Religiosity is a concept used as a measure, or standard, to determine the level to which one abides by religion. Personal religiosity is helpful in discovering variance between individuals relating to their moral judgments (Abou-Youssef, Kortam, Abou-Aish, \& El-Bassiouny, 2015). These religious beliefs and judgments influence the purchase and consumption 
patterns of Muslim consumers. Moreover, the Muslim consumers who understand and follow the Sharia principles have a greater tendency to demand Islamic products and services (Johan \& Putit, 2016). Therefore, religiosity is regarded as a central concept in several consumer behavior studies that encourages consumers to consider religion when buying products or services (Elseidi, 2018). The halal product concept emerged from increased demand for religion-focused products. This concept has greatly influenced the consumption patterns of Muslim consumers in all walks of life. Today, halal products and practices are found in dietary goods, the fashion and tourism industries, cosmetics and personal care products, healthcare services, financial institutions, and chemical and material industries. Businesses are now focusing on growing the halal aspect of their businesses, which is worth more than \$2.1 trillion annually. Leading organizations including McDonalds, Nestlé, Walmart and Unilever are also targeting this segment by introducing separate lines of halal products (Izberk-Bilgin \& Nakata, 2016).

The banking sector has also witnessed a substantial growth in demand for halal financial products, with $11 \%$ growth in comparison to $7 \%$ growth in conventional banking assets over the previous five years (IFDI, 2018). Therefore, the concept of Islamic banking is now widespread in many countries, such as Saudi Arabia, Turkey, the UAE, Kuwait, Egypt, Sudan, and Jordan, since 1970. In Pakistan, Islamic banking emerged in 1960 in response to religious and constitutional requirements. However, this transformation without a proper operational and regulatory framework did not produce the desired results. Therefore, an improved version of the Sharia-compliant banking system was re-launched in 2001-02 by the State Bank of Pakistan (SBP). In Pakistan, Meezan Bank was the first bank to be licensed under the new Islamic banking system. Currently there are twenty-one Islamic banks operating in Pakistan, among them five banks have fully-fledged Islamic services and sixteen banks with standalone Islamic banking services (Islamic Bank Bulletin, 2018). The SBP has established a Sharia board to oversee the implementation and compliance with Islamic banking principles in Pakistan (Salman \& Nawaz, 2018). The Sharia board monitors the compliance of Sharia practices and ensures all activities are conducted on the basis of ideologies and principles laid down by Islam. Islamic banks run their businesses according to the principles of Islam that do not permit "riba" (charged interest) (Wulandari \& Subagio, 2015). Sharia not only forbids paying to borrow money, but also forbids unethical practices. In commercial banking, only rewards are shared in the form of interest, but Islamic law shares risk and reward equally. In Islamic banking, there are four principles of Sharia used as alternatives to interest-based banking products. These principles are based on profit and loss sharing, such as mudarabah and musharakah, fee- or charges-based, such as murabahah and ijarah, free services, such as qard alhassan, and additional services, such as wadiah (Kamarulzaman \& Madun, 2013).

Islamic banking has grown since the re-launch of Sharia-compliant banking in Pakistan, and almost every bank is now offering Islamic banking products. This growth has created competition among banks and investment and insurance firms offering Sharia-compliant financial products (Al-Salem \& Mostafa, 2019), and consequently, management is under pressure to attract new customers and retain their current customers of Islamic financial products. Therefore, banks need to reconsider their marketing strategies and design a separate strategy focusing on the Sharia requirements and religiosity of customers, known as faith-based or religiosity-based strategies (IzberkBilgin \& Nakata, 2016). Banks offering Islamic products need to attract potential customers by redesigning their marketing strategies taking the local aspects of Pakistan into account. These marketing strategies should primarily focus upon addressing the religious sensibilities in financial markets with religion-friendly products that are fully Sharia-compliant (Al-Kwifi, Farha, \& Ahmed, 2019). This religiosity-based marketing strategy helps banks to compete against other businesses and attract customers to their Islamic financial products. Muslim customers are religiously sensitive to financial matters and require assurance of strict compliance with Islamic principles to enter into financial contracts with banks. Therefore, banks need to attract customers by convincing them through religiosity-based marketing strategies that their Islamic banking products are in line with Sharia requirements (Izberk-Bilgin \& Nakata, 2016). This claim is further supported by existing literature that religiosity-based marketing equally influences the attitudes of customers toward Islamic banking products (Zebal \& Saber, 2014). 
Especially, religiosity-based marketing helps to shape the purchase behavior of current Muslim customers, who are better educated and savvier than previous generations. These customers are more concerned with purchasing Islamic, yet modern, products including financial products (Pink, 2009). There are more affluent customers in this group who are drawn to modern products in accordance with their faith, and targeting this segment with religiosity-based marketing strategies could facilitate banks in attracting them to Sharia-compliant products and thus increase their customer base (Izberk-Bilgin \& Nakata, 2016).

Researchers have not yet tried to understand the role of religiosity-based marketing in influencing the buying behavior of Muslim customers (El-Bassiouny, 2014). Therefore, this research aims to address this gap by developing a conceptual model based on constructs grounded in literature to investigate the role of religiosity-based marketing in driving the purchase of Islamic banking products. By investigating these structural relationships on the basis of quantitative methodology, this research extends the role of religiosity-based marketing in shaping the behavior of Pakistani customers toward Islamic financial products. This study also adds depth to the consumer behavior knowledge base by investigating consumer behavior regarding Islamic financial products in a Pakistani context. Furthermore, this study strengthens the implementation of marketing strategies based on religiosity, as a non-traditional marketing element, to target Muslim consumers. More specifically, this study aims to evaluate the role of religion-based marketing in gaining customers through the mediating roles of credibility, word of mouth and customer relationships.

\section{LITERATURE REVIEW AND HYPOTHESES DEVELOPMENT}

\subsection{Religiosity-based Marketing}

The competition between businesses has pressurized them to capitalize on each sector of the market to improve their sustainability and profitability, and this has ledreligion to become a very lucrative sector with plenty of religion-compliant products being offered to consumers. Religions are now regarded as brands-termed as brands of faith — to not only compete against each other, but against conventional brands (Einstein, 2007; Gauthier, 2016). Religiosity-based marketing follows strategies, tools, and principles similar to conventional marketing and places emphasis on marketing religion-compliant offerings to align with the religious values of consumers. Religionconscious consumers prefer to buy Islamic products to meet their religion obligations and to teach the value of religion to their next generations (Preda, 2019). Therefore, the religiosity-based branding of many products, including food, stationery products, toys, cosmetics, financial products, and many more, is a common practice in many countries. Religious consumers constitute a fast growing sector with considerable spending power (Hutchins \& Stielstra, 2009) and, therefore, religiosity-based marketing strategies are employed to target this untapped and profitable sector (Izberk-Bilgin \& Nakata, 2016). However, financial products, contrary to other Islamic products, need strict Shariacompliance and are more difficult to choose among similar offerings (Wilson, 2012), which makes the decision-making process more complex and requires clear understanding. This is the reason that religiositybased marketing is considered to be the most important tool in facilitating the decision-making process regarding Islamic banking products. Targeted campaigns help banks to differentiate their offerings from competing ones by ensuring strict compliance and providing clarity over weak compliance and unclear offerings (Alserhan, 2017). However, a profound understanding of the purchase behavior of religious consumers is required while designing such campaigns (Tabrani, Amin, \& Nizam, 2018).

Similar to consumers' purchase behavior towards conventional products, the social norm theory (SNT), the theory of planned behavior (TPB), and the theory of reasoned action (TRA) also help to explain customers' attitudes and behavior towards Islamic products (Aziz \& Chok, 2013; Bashir, Bayat, Olutuase, \& Abdul Latiff, 2019; Hussain., Rahman, Zaheer, \& Saleem, 2016; Lada, Tanakinjal, \& Amin, 2009; Mukhtar \& Butt, 2012; Shafie \& Othman, 2006). According to previous studies, the behavior of Islamic customers is largely influenced by the marketing initiatives in line with these theories (Amin, 2012). However, marketing aimed at faith or religion is a 
very sensitive matter and requires comprehensive strategies to convince religious customers, but specific marketing is required to target these customers and influence their purchase behavior (Cantrell \& Yust, 2018).

There is a huge opportunity for banks to market financial products to Muslim consumers and to develop and improve the purchase intentions of customers (Al-Salem \& Mostafa, 2019), as previous studies have found that religiosity directly affects purchase behavior (Rahayu, Setiawan, Irawanto, \& Rahayu, 2020). However, growing the number of customers of Islamic financial products involves substantial challenges, such as operational, cultural, and geographical differences (Izberk-Bilgin \& Nakata, 2016). In the banking industry, religiosity-based marketing campaigns supported by principles laid by the Sharia board are more powerful and trustworthy tools in developing relationships with customers than conventional and relationship-focused campaigns (Al-Salem \& Mostafa, 2019). This is because Sharia board members have more persuasive power than customers' opinions and are stronger and more convincing than ordinary marketing strategies (Izberk-Bilgin \& Nakata, 2016). Customers refer to the principles of the Sharia board when speaking to people in their social networks, which creates awareness of these principles and generates positive word of mouth (Auf, Salleh, \& Yusoff, 2016). Religiosity-based marketing strategies help to safeguard customers' investment in Islamic products, and providing guarantees makes banks more credible because a credible bank promises to build and maintain its transparency, reputation and independence (Henckel, Menzies, Moffatt, \& Zizzo, 2019; Walsh, 2009).

\subsection{Credibility}

Credibility of products is the degree to which consumers perceive the product or brand to be trustworthy, expert, and relatable (Keller, 2013). The measurement of product, service and organizational credibility is an ongoing concern for researchers. Similarly, credibility is becoming universally important for banks, academics and practitioners in attracting and retaining customers. In the banking system, credibility describes the compliance of well-articulated and transparent policies and principles, and a strong belief that a change in policy is actually implemented (Henckel et al., 2019).

Religiosity with high credibility contains the spiritual and religious values of a specific Islamic bank that shows spiritual attachment between Islamic banks and their customers. The relationship theory argues that banks that are successful in gaining the trust of customers by offering credible products have better chances of developing long term relationships with them (Kabadayi, 2016). Credibility itself is a perceived intentional behavior in choosing the services of Islamic banks (Tabrani et al., 2018). Therefore, banks need to be trustworthy and credible to be successful and secure long-term relationships with customers (Kotler, Keller, Ang, Tan, \& Leong, 2018). In Islam, faith and steadfastness are considered to be the base of a believer's character (Iqbal \& Mirakhor, 2007). In this way, the main ideas behind faith are trustworthiness and steadfastness, and ethical and moral values, which all are constructed in the professional interaction between customers and banks (Hanafi \& Sallam, 1997).

The credibility of the Islamic way of banking is continuously increasing due to the establishment of Sharia boards and compliance with Islamic financial business rules. Furthermore, banks' credibility and religious-based guarantees have been improved by strengthening the religious audit system (Haridan, Hassan, \& Karbhari, 2018). The Sharia Supervisory Board (SSB) increases the credibility of Islamic banks for their customers through establishing Islamic identifications as a part of the internal governance structure of the institution. It is the responsibility of the SSB to guarantee the credibility of Islamic banks through implementing and strictly obeying Sharia principles (Zainuldin, Lui, \& Yii, 2018). Furthermore, the SSB has to conduct regular reviews to ensure that Islamic banks are truly following Sharia rules, their customers are being offered the best products and services, and their personal interests are also being protected (Garbarino \& Johnson, 1999). In this respect, banks have an opportunity to elevate the credibility of their offerings through designing effective marketing strategies and by decreasing customer uncertainty and decision-making cost as consumers prefer to purchase credible products with 
few risk factors (Jeng, 2016). Therefore, the credibility of products can be strengthened through the religiositybased marketing that ultimately supports customer purchase intentions.

\subsection{Word of Mouth (WoM)}

Word of mouth is the informal discussion or exchange of views based on product or service experience and the degree of customer satisfaction or dissatisfaction (Martin, 2017). Word of mouth has a definite reputation in the marketplace and is considered as a casual topic among the different sectors of the community regarding the various services irrespective of the company to whom these belong. People are normally more attracted to avail customer support services when buying is particularly risky, being purchased occasionally, involve complexity in decisionmaking and have a high social rank (Litvin, Goldsmith, \& Pan, 2018).

Word of mouth directly influences the decision-making process because buyers make decisions based on recommendations from peers, thus decreasing any uncertainty and potential cost of a decision to purchase goods and services (Zhang, Li, Cao, \& Huang, 2018). In particular, it influences the buying intentions of young people who communicate with their friends and peers before making decisions and heavily rely on recommendations from people in their social networks (Alam, Mohd, \& Hisham, 2011). Recent research found that positive word of mouth increases the reputation of a brand as well as the organization. Same is the true for banking customers who seek positive reviews via word of mouth before buying a financial package to minimize confusion and risks associated with financial matters (Hanaysha \& Pech, 2018).

In the banking system, verbal communication is very effective in creating awareness in the market of financial products, and indirectly influencing or facilitating the purchase decisions of customers in order to increase the customer base (Xu, Guo, Xiao, \& Zhang, 2018). This fact is supported by a theory of communication, known as the Attention-Interest-Desire-Action (AIDA) model, proposed by Lewis in 1989. According to the AIDA model, persuasive communication plays a key role in purchase decisions. The awareness and positive customer feedback help customers to understand the message conveyed by marketing campaigns (Hassan, Ahmad Nadzim, \& Shiratuddin, 2015). Word of mouth generates truth and authenticity and influences the purchase process of the customers (Wijaya, 2015), since through verbal communication, customers' views spread positive feedback about products or services and high levels of customer service (Mukerjee, 2018). The word of mouth theory ascertains that verbal communication is a vibrant source of information generated by customers or marketers and dispersed to other potential consumers. It is a very useful tool that helps potential customers to evaluate a product or service before its purchase or consumption (Iqbal. \& Hassan, 2018). Similarly, recommendations and suggestions from relatives and friends strongly influence customers to by financial services offered by Islamic banks (Amin, Rahim, \& Abdul Razak, 2014).

\subsection{Customer Relationship}

A relationship is defined as a "series of interaction episodes that make relational ties between interacting parties" (Buttle \& Maklan, 2019). Relationship marketing theory argues that management of customer relationships depends on the strength of relational ties between a service provider and service receiver, and enables firms to retain existing strategically important customers, develop more trustworthy relational ties and enhance their customer base with profitable customers (Balaji, 2015). The success of the banks offering Islamic products mainly depends on establishing, maintaining and nurturing relationships with customers with the intention of developing long-lasting customers of the Islamic depository (Beck, Ongena, \& Şendeniz-Yüncü, 2019). The relationship and communication approaches are helpful in avoiding any misconceptions about the operations of Islamic banking relating to Islam. This technique can attract customers who wish to make financial investments or savings decisions according to the teachings of Islam (Souiden \& Rani, 2015). Moreover, the extent of interactions establishes the relationship with customers, which, in turn, encourages them to consider Islamic products (Tjiptoherijanto \& 
Balqia, 2017). Islamic banks have wisely managed and created a purely Islamic atmosphere that leads to a favorable perception of Islamic banks. Management has invested heavily in the training of customer service representatives (CSRs) and customer relations advisors (CRAs) to effectively deal with customers and to develop personal relationships with them by providing a superior service. The provision of training, and the development of a monitoring system, helped management to deliver quality services and monitor daily sales activities in view of the Islamic code of conduct (Khan, Sayyam, \& Rahman, 2017). These initiatives have immensely contributed to the credibility of banks, development of customer purchase intentions, establishing relationships with Islamic banks and in generating repeat purchases with a larger share of wallet (Tabrani et al., 2018).

\subsection{Customer Purchase Intentions}

According to the theory of planned behavior (TPB), attitudes depend on religiosity to encourage customers to purchase Islamic products (Ajzen, 1991; Souiden \& Rani, 2015). Religious beliefs shape the attitude of customers to have the favorable behaviors toward Islamic products (Fishbein \& Ajzen, 1975). Religiosity-based marketing communicates Islamic messages and persuades customers to purchase products by exploiting their faith. As a result, the persuasive Islamic communication serve as the underlying basis to develop the positive attitude of the individuals who have more religious concerns and alter their buying behaviors and spending patterns (Akbari, Gholizadeh, \& Zomorrodi, 2018).

Social pressure from friends and relatives may influence or inspire customers to use Islamic methods of banking. The theory of planned behavior points out three fundamental elements in developing intentions: attitude towards behavior, perceived behavior control, and subjective norms. The important belief factors, including religiosity, business support reputation, knowledge, and awareness are positively associated with attitudes towards Islamic banking and, subsequently, influence customer intentions to purchase Islamic financial products (Jaffar \& Musa, 2016). Nowadays, due to considerable competition within the market and improved customer information, it has become difficult to win customers from competitors. Therefore, organizations are required to have a comprehensive understanding of consumer behavior and the segmentation bases for strategically important customers. Among these segmentation bases, the religious segment could better be targeted by designing an exclusive marketing campaigns to convince segment members to react favorably toward Islamic banking products (Bashir et al., 2019; Suhartanto, 2019).

Based on the above theoretical considerations, the model presented below in Figure 1 was proposed for this study.

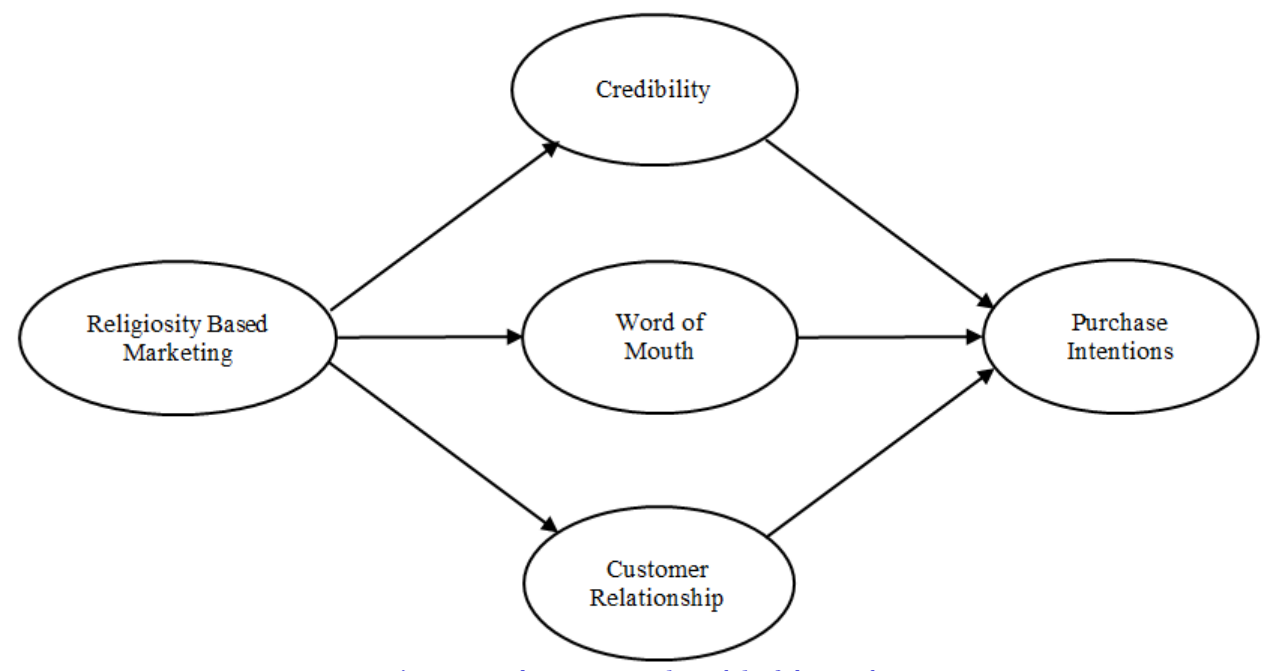

Figure 1. The conceptual model of the study. 
The following hypotheses and conceptual models are proposed after reviewing the relevant literature:

H1: Religiosity-based marketing has positive and significant contribution to the development of a bank's credibility, positive word of mouth, and building strong customer relationships.

H2: Credibility significantly and positively contributes to the development of purchase intentions.

H3: Positive word of mouth significantly and positively contributes to the development of purchase intentions.

H4: Strength of customer relationships significantly and positively contributes to the development of purchase intentions.

\section{MEASUREMENT AND DATA COLLECTION}

The sample for the study was taken from people using services from both Islamic and conventional banks in the Gujranwala Division of Pakistan, as all the main banks operating in Pakistan have branches in this location. This division is known as the "Golden Triangle" due to the high level of business activity in the Gujranwala, Gujrat and Sialkot districts. The sample size was calculated according to the recommendation by Hair, Black, Babin, Anderson, \& Tatham, (2006) to collect ten responses to each question. The questionnaire for this research comprised fortyfour items and a sample of 440 respondents was finalized. The convenience sampling technique was used to gather the data, as respondents were from the general public with no availability of a sampling frame from the banks operating in the Gujranwala division.

All scales were adapted from previous studies. Religion-based marketing was assessed using a 10-item scale $(\alpha=.85)$ adapted from Awan, Siddiquei, and Haider (2015) and Abou-Youssef et al. (2015); credibility was assessed using a 16-item scale $(\alpha=.92)$ from West (1994); word of mouth was assessed using an 8-item scale $(\alpha=.94)$ adapted from Dolen, Dabholkar, and De Ruyter (2007) and Goyette, Ricard, Bergeron, and Marticotte (2010); customer relationship was assessed using a 5-item scale $(\alpha=.81)$ from Demo, Watanabe, Chauvet, and Rozzett (2017); and purchase intentions of banking customers were measured using a 5 -item scale $(\alpha=.89)$ from Amin, Rahim, Laison, and Magdalene (2011). Religiosity-based marketing and word of mouth were measured by selecting items from two scales. These items were selected on the basis of their operational proximity to empirical levels to measure the latent construct (Bhattacherjee, 2012).

Table 1. Demographic profile of respondents.

\begin{tabular}{|c|c|c|c|c|c|}
\hline Characteristics & $\mathbf{N}$ & \% age & Characteristics & $\mathbf{N}$ & $\%$ age \\
\hline \multicolumn{3}{|l|}{ Age } & \multicolumn{3}{|c|}{ Gender } \\
\hline $18-25$ & 110 & 25 & Male & 213 & 48.4 \\
\hline $26-30$ & 174 & 39 & Female & 227 & 51.6 \\
\hline $31-35$ & 99 & 22 & \multicolumn{3}{|c|}{ Income } \\
\hline 36 and over & 55 & 12 & Below 50,000 & 104 & 23.6 \\
\hline \multicolumn{3}{|l|}{ Education } & $50,001-100,000$ & 165 & 37.5 \\
\hline Metric & 35 & 8 & $100,001-150,000$ & 96 & 21.6 \\
\hline Inter & 63 & 14.3 & $150,001-200,000$ & 69 & 15.9 \\
\hline Bachelor & 128 & 29.1 & $\begin{array}{c}\text { 200,0001 and } \\
\text { above }\end{array}$ & 6 & 1.4 \\
\hline Masters & 156 & 35.5 & \multicolumn{3}{|c|}{ Owns a car } \\
\hline MPhil & 58 & 13.2 & Yes & 147 & 33.4 \\
\hline \multicolumn{3}{|c|}{ Type of banking services } & No & 293 & 66.6 \\
\hline Current A/C & 162 & 36.8 & \multicolumn{3}{|c|}{ Using loan facilities } \\
\hline Saving $\mathrm{A} / \mathrm{C}$ & 114 & 25.9 & Yes & 90 & 20.5 \\
\hline Fixed A/C & 62 & 14.1 & No & 350 & 79.5 \\
\hline $\mathrm{P} / \mathrm{L} \mathrm{A} / \mathrm{C}$ & 27 & 6.1 & \multicolumn{3}{|c|}{ Has information about Islamic banking } \\
\hline \multirow[t]{2}{*}{ Other services } & 75 & 17 & Yes & 333 & 75.7 \\
\hline & & & No & 107 & 24.3 \\
\hline
\end{tabular}

The item response theory (IRT) provided the basis for two developed scales to measure a construct (Gibbons, Perraillon, \& Kim, 2014). The questionnaire consisted of two parts, the demographic information of respondents, 
and the items of the aforementioned scales. All the items were assessed using a 5-point Likert scale $(1=$ strongly disagree and $5=$ strongly agree). Data collection continued until 440 valid and complete responses were gathered. The data was then screened by treating missing values, engagement of respondents, and outliers. Partial least square structural equation modelling (PLS-SEM) was used by employing Smart-PLS version 3.2.8.

The conceptual model was tested in two steps. First, the sample demographic characteristics were analyzed using frequencies and percentages. In the first step, the evaluation of measurement (outer) model was done involving reliability and validity, i.e. convergent validity (alpha values, composite reliability, and average variance extracted (AVE), discriminant validity, (Hetero-trait-monotrait (HTMT) ratio and Fornell and Larcker criterion) tests. In the second step, the evaluation of the structural (inner) model was done using bootstrapping with a subsample of 5000 and path analysis (Chin \& Newsted, 1999). The fitness of the model was assessed by standardized root mean square residual (SRMR), chi-square, normalized fit index (NFI), and goodness of fit (GOF) using d-ULS (Unweighted least squares discrepancy) and d-G (geodesic discrepancy) tests.

\section{RESULTS}

First of all, the demographics of the respondents were analyzed, and the results are presented in Table 1. The profile of each demographic variable is presented in numbers and their relative percentages.

In this study, an almost equal number of males (213) and females (227) participated and registered their responses.

Table 2. Factor loads and variation inflation factor.

\begin{tabular}{|c|c|c|c|}
\hline Variable Name & Measures & Outer Loads & VIF \\
\hline \multirow[t]{6}{*}{ Religiosity } & Religiosity3 & 0.735 & 1.746 \\
\hline & Religiosity 5 & 0.833 & 2.376 \\
\hline & Religiosity6 & 0.904 & 3.700 \\
\hline & Religiosity 7 & 0.848 & 2.556 \\
\hline & Religiosity 8 & 0.852 & 2.670 \\
\hline & Religiosity 10 & 0.871 & 2.890 \\
\hline \multirow[t]{10}{*}{ Credibility } & Credibility3 & 0.803 & 2.547 \\
\hline & Credibility 4 & 0.833 & 3.116 \\
\hline & Credibility 5 & 0.885 & 3.008 \\
\hline & Credibility6 & 0.839 & 3.289 \\
\hline & Credibility 7 & 0.811 & 2.653 \\
\hline & Credibility 8 & 0.848 & 3.231 \\
\hline & Credibility9 & 0.866 & 3.291 \\
\hline & Credibility 11 & 0.845 & 3.035 \\
\hline & Credibility 12 & 0.832 & 2.845 \\
\hline & Credibility 13 & 0.827 & 2.952 \\
\hline \multirow[t]{8}{*}{ Word of Mouth } & WoM1 & 0.834 & 2.756 \\
\hline & WoM2 & 0.843 & 2.885 \\
\hline & WoM3 & 0.853 & 2.910 \\
\hline & WoM4 & 0.818 & 2.493 \\
\hline & WoM5 & 0.855 & 2.937 \\
\hline & WoM6 & 0.828 & 2.544 \\
\hline & WoM7 & 0.861 & 2.069 \\
\hline & WoM8 & 0.841 & 2.667 \\
\hline \multirow[t]{5}{*}{ Relationship } & Relationship 1 & 0.827 & 2.202 \\
\hline & Relationship2 & 0.841 & 2.265 \\
\hline & Relationship3 & 0.843 & 2.351 \\
\hline & Relationship4 & 0.862 & 2.485 \\
\hline & Relationship5 & 0.849 & 2.358 \\
\hline \multirow[t]{5}{*}{ Customer Intention } & Customer Intention 1 & 0.828 & 2.022 \\
\hline & Customer Intention2 & 0.812 & 1.887 \\
\hline & Customer Intention3 & 0.787 & 2.890 \\
\hline & Customer Intention4 & 0.803 & 1.895 \\
\hline & Customer Intention5 & 0.720 & 1.565 \\
\hline
\end{tabular}


The majority of the respondents (87\%) were aged between $18-35$, and the remaining $13 \%$ were above 35 . People under 35 years of age are in the early stages of their careers, which is when most bank accounts are opened. Therefore, this age group is a sizeable retail segment that needs to be targeted and facilitated in their decisionmaking process. Table 1 shows that respondents were mostly educated, and a large number of respondents (62\%) had income less than Pakistani Rupees (PKR) 100,000 and very few had income above PKR 200,000. The majority of respondents $(76 \%)$ were familiar with the Islamic banking system, and a of the remaining respondents $(24 \%)$ were not aware of the Islamic banking system.

The analysis of the measurement models is presented in Table 2. It shows that all had variance inflation factors (VIF) within cut-off level 5. All items measuring the corresponding latent variable structure had loadings larger than 0.7 as recommended by Hair, Ringle, and Sarstedt (2013). All constructs displayed adequate internal consistency reliability as the Cronbach alpha coefficients exceeded a value of 0.7. Furthermore, the remaining construct (variables) revealed good internal consistency and reliability. Table 3 includes reliability, convergent validity, and discriminant validity measures. The value of Cronbach's alpha reliability test indicated that all the constructs were reliable with the alpha value higher than 0.7 as recommended by Nunnally (1978). The average variance extracted (AVE) value of the constructs also exceeded the cut-off value of 0.5 as recommended by Fornell and Larcker (1981), and the composite reliability exceeded the cut-off value of 0.7 as recommended by Hair et al. (2013). Similarly, all other parameters determined that reliability and convergent validity were above the threshold values.

Table 3. Construct validity and reliability.

\begin{tabular}{c|c|c|c|c|c}
\hline Name of Variable & Religiosity & Credibility & WoM & Relationship & Intention \\
\hline Religiosity & 0.842 & & & & \\
\hline Credibility & 0.802 & 0.842 & & & \\
\hline WoM & 0.765 & 0.817 & 0.840 & & \\
\hline Relationship & 0.835 & 0.817 & 0.828 & 0.844 & \\
\hline Intention & 0.859 & 0.752 & 0.818 & 0.821 & 0.791 \\
\hline Cronbach's alpha & 0.923 & 0.942 & 0.954 & 0.900 & 0.854 \\
\hline Composite reliability & 0.936 & 0.951 & 0.960 & 0.925 & 0.893 \\
\hline (AVE) & 0.709 & 0.709 & 0.704 & 0.713 & 0.626 \\
\hline
\end{tabular}

The goodness of fit of the model was measured using SRMR and NFI tests (Henseler et al., 2014), and the results are presented in Table 4. The recommended criteria for SRMR is $\leq$ 0.08. The proposed model has an SRMR value of 0.039 less than the criteria. Therefore, the proposed model is fitted as per standard requirements (Hair et al., 2013; Henseler et al., 2014). Second, in literature it is recommended that NFI values should fall between 0 and 1, and the value closer to 1 is the better fit (Ringle, Wende, Becker, \& Gmb, 2017). Table 4 shows that value of NFI is 0.881 , which is closer to 1. Therefore, it is concluded based on SRMR, NFI and other model fitness values given in Table 4, that this model is a good fit (Bentler \& Bonett, 1980; Dijkstra \& Henseler, 2015). Figure 2 represents the fitted model of the study.

Table 4. Model fit summary.

\begin{tabular}{c|c}
\hline Measures & Values \\
\hline SRMR & 0.039 \\
\hline d- ULS & 0.925 \\
\hline d- G1 & 0.786 \\
\hline d- G2 & 0.681 \\
\hline Chi-square & $1,660.585$ \\
\hline NFI & 0.881 \\
\hline
\end{tabular}

Note: SRMR (Standardized root means square residual), d-ULS (Unweighted least squares discrepancy), d-G (geodesic discrepancy), and NFI (Normalized Fixed Index). 
The results presented in Table 5 show that the relationship between religiosity-based marketing and credibility, word of mouth and consumer relations is positive and significant. Therefore, hypothesis 1 , that religiosity-based marketing has a significant and positive influence on credibility, word of mouth and customer relationship, is accepted. The results shown in Table 5 highlight that the relationship between credibility and purchase intention is not significant, therefore hypothesis 2 is rejected. Results depict that word of mouth and, similarly, customer relations are also significantly and positively associated with purchase intentions, therefore, hypotheses 3 and 4 are also supported by the results.

Table 5. Effect decomposition.

\begin{tabular}{|c|c|c|c|}
\hline Path & Coefficients & T Statistics & P VALUE \\
\hline Religiosity $\rightarrow$ word of mouth & 0.747 & 28.811 & 0.000 \\
\hline Religiosity $\rightarrow$ credibility & 0.799 & 38.317 & 0.000 \\
\hline Religiosity $\rightarrow$ relationship & 0.761 & 29.119 & 0.000 \\
\hline Religiosity $\rightarrow$ purchase intentions & 0.174 & 4.077 & 0.000 \\
\hline Word of mouth $\rightarrow$ purchase intentions & 0.369 & 4.677 & 0.000 \\
\hline Credibility $\rightarrow$ purchase intentions & 0.063 & 0.847 & 0.397 \\
\hline Relationship $\rightarrow$ purchase intentions & 0.345 & 5.522 & 0.000 \\
\hline Religiosity $\rightarrow$ word of mouth $\rightarrow$ purchase intentions & 0.276 & 4.584 & 0.000 \\
\hline Religiosity $\rightarrow$ credibility $\rightarrow$ purchase intentions & 0.051 & 0.840 & 0.401 \\
\hline Religiosity $\rightarrow$ relationship $\rightarrow$ purchase intentions & 0.262 & 5.513 & 0.000 \\
\hline
\end{tabular}

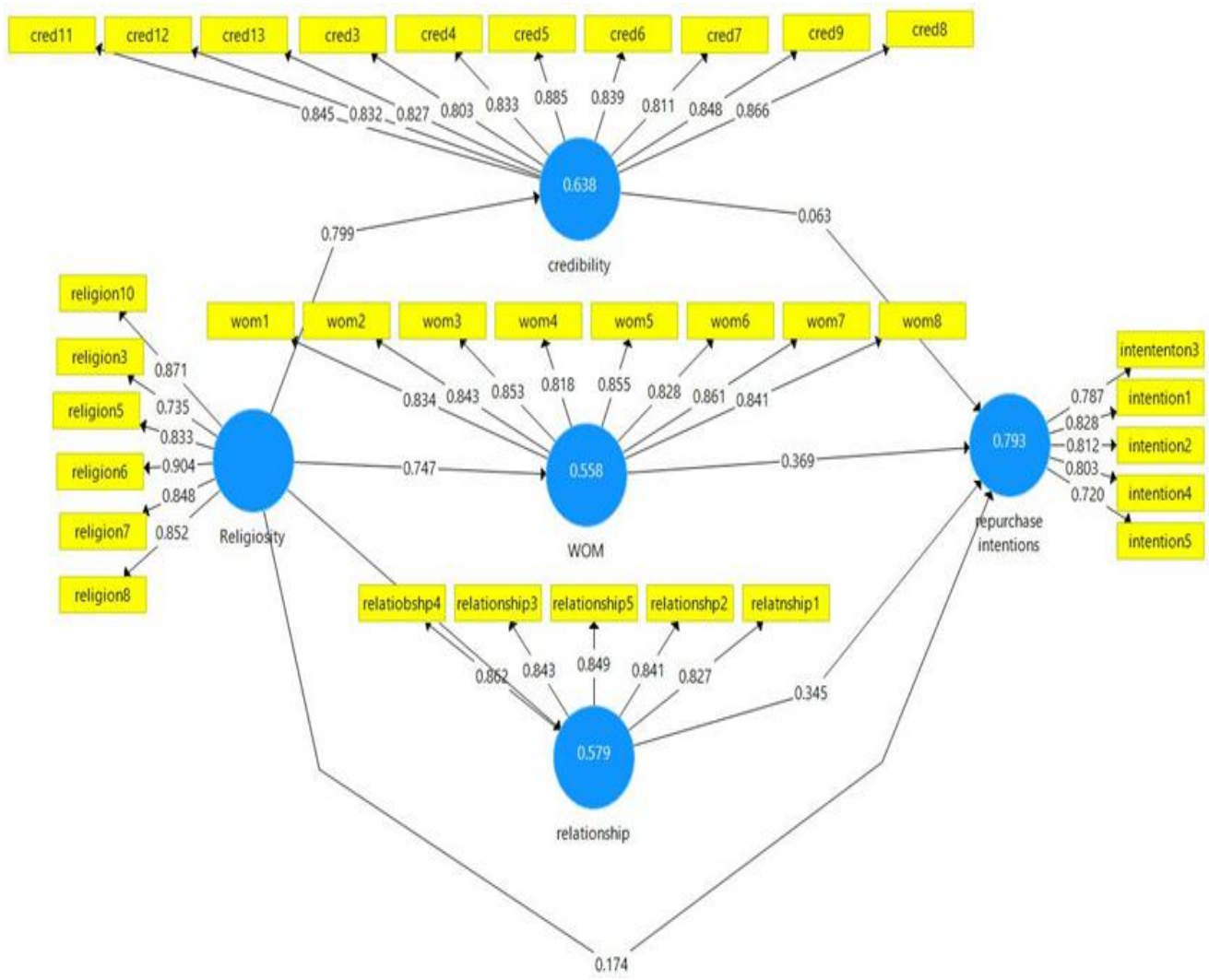

Figure 2. Fitted model of the study.

\section{DISCUSSION}

It is notable that the relationship between religiosity-based marketing, credibility, word of mouth and customer relation constructs represents higher values. This is because Muslim customers have a high level of religious attachment and are sensitive about their faith (Izberk-Bilgin \& Nakata, 2016). The results reveal that banks have a better chance of developing their credibility and relationships with customers by implementing religiosity-based marketing strategies. This is possible when the Islamic products offered by banks are fully endorsed by the Sharia 
board and are supported by a specific marketing campaign. These results reinforce that religiosity-based marketing enhances the credibility of banks as well as religious identities where norms and beliefs are involved (Lanman \& Buhrmester, 2017). Similarly, religiosity-based marketing positively influences word of mouth and facilitates the customer decision-making process through positive awareness among the general public (Jridi, Chaabouni, Bakini, \& Harbaoui, 2018), and a higher perceived value of the offerings (Mahadin \& Akroush, 2019). Furthermore, focusing on religiosity-based marketing helps to develop a trust-based relationship between banks and customers by minimizing religious ambiguities and ensuring a clear understanding of Islamic products (Skarmeas \& Shabbir, 2011).

The results also show that word of mouth mediates religiosity-based marketing and purchase intentions relationships (Zhang et al., 2018). This means that a faith-based marketing campaign generates positive word of mouth in the market and strongly influences the buying intentions of consumers as argued by Kudeshia and Kumar (2017). Verbal communication influences the decision-making process of other people and the preparedness of customers to buy products and services (Huete-Alcocer, 2017; Hussain. et al., 2016). Generally, verbal communication is observed as a more reliable and trustworthy source than other sources generated by organizations to communicate with their potential audience. Additionally, it can significantly affect winning new business from consumers (Allsop, Bassett, \& Hoskins, 2007). The findings indicate that there is a strong contribution of WOM credibility, WOM quantity, and WOM quality in customer buying intentions (Bataineh, 2015).

Strong relationships with customers always pay back to the organization, therefore, an organization needs to effectively manage relationships to attract and retain strategically important customers (Buttle \& Maklan, 2019). The study shows a significant association between customer relationships and purchase intentions, and also reveals that customer relationships significantly mediate the structural connections between religiosity-based marketing and purchase intentions (Al-Salem \& Mostafa, 2019). Results of recent studies supported the fact that maintaining strong relationships with customers, and the provision of excellent customer service, has profoundly influenced customers' willingness to buy Islamic products and services. Therefore, banks would benefit from training their sales teams in the development of strong relationships with customers by strengthening their customer service (Tabrani et al., 2018).

\section{CONCLUSION}

This research evaluates the contribution of religiosity-based marketing in winning customer intentions. This type of marketing is required to improve credibility, positive word of mouth and customer relationships. Since banks are known as providers of interest-based financial services, offering Islamic products under the same name creates confusion and difficulty in accepting the standalone existence of Islamic products or services. It is evident from the results that in the current scenario, customers are not willing to purchase Islamic products solely on the basis of credibility. Therefore, a comprehensive religion-focused marketing strategy needs to be implemented to convince customers to purchase Islamic products. Islamic banks and commercial banks offering Islamic products can gain credibility by accurately following Sharia guidelines while offering financial products and services. Once, the banks gain credibility by offering purely Islamic products, word of mouth and customer relationships will improve further and will influence purchase intentions. The contributions of this study includes; first, that religiosity-based marketing in Pakistan is an effective tool to convince people to buy Islamic products; second, credibility of commercial banks does not contribute to the purchase decisions of customers regarding Islamic products; and third, the tested model provides a guideline for the design of a comprehensive religiosity-based marketing campaign to enhance the purchase intentions of customers of Islamic products in Pakistan.

There are a number of reasons that banks are required to design specific religiosity-based marketing strategies to win new customers. First, the commercial banking system is a better-established system than the Islamic 
banking system in Pakistan (Rashid \& Jabeen, 2016). Second, there are very few specifically Islamic banks in Pakistan and most financial products are offered by commercial banks. Although, conventional banks are credible, their credibility does not influence purchase intentions (Saqib, Farooq, \& Zafar, 2016). Third, the general public is not convinced that Islamic banking products strictly follow Sharia principles (Hussain, Qureshi, \& Nazir, 2018), therefore, religiosity-based marketing can help the banks to present standalone Islamic banking products along with conventional financial services.

\section{LIMITATIONS AND FUTURE DIRECTIONS}

This study has some limitations along with the aforementioned contributions. The first limitation is the collection of responses on religiosity-based marketing as an accumulative measure, however, there are many sects that have a different point of view regarding financial products and services. Therefore, a separate sect-based study will help banks to effectively target each segment. Second, the study is based on a cross-sectional design, therefore the causal relationships need to be carefully interpreted from the results. In future, a longitudinal study design could be used to observe changes in consumer behavior over time. Third, the moderating role of demographic variables is not evaluated in this study, so the moderating role of some variables like age, gender, education and financial status can be studied at a later date to extend the findings of this study.

Funding: This study received no specific financial support.

Competing Interests: The authors declare that they have no competing interests

Acknowledgement: All authors contributed equally to the conception and design of the study.

\section{REFERENCES}

Abou-Youssef, M. M., Kortam, W., Abou-Aish, E., \& El-Bassiouny, N. (2015). Effects of religiosity on consumer attitudes toward Islamic banking in Egypt. International Journal of Bank Marketing, 33(6), 786-807.

Ajzen, I. (1991). The theory of planned behavior. Organizational Behavior and Human Decision Processes, 50(2), $179-211$.

Akbari, M., Gholizadeh, M. H., \& Zomorrodi, M. (2018). Islamic symbols in food packaging and purchase intention of Muslim consumers. Journal of Islamic Marketing, 9(1), 117-131.

Al-Kwifi, O. S., Farha, A. A., \& Ahmed, Z. U. (2019). Dynamics of Muslim consumers' behavior toward Halal products. International Journal of Emerging Markets, 14(4), 689-708.

Al-Salem, F., \& Mostafa, M. M. (2019). Clustering Kuwaiti consumer attitudes towards Sharia-compliant financial products: A self-organizing maps analysis. International Journal of Bank Marketing, 37(1), 142-155.

Alam, S. S., Mohd, R., \& Hisham, B. (2011). Is religiosity an important determinant on Muslim consumer behaviour in Malaysia. Journal of Islamic Marketing, 2(1), 83-96.

Allsop, D. T., Bassett, B. R., \& Hoskins, J. A. (2007). Word-of-mouth research: Principles and applications. Journal of Advertising Research, 47(4), 398-411.

Alserhan, B. A. (2017). The principles of Islamic marketing: Routledge.

Amin, H. (2012). Patronage factors of Malaysian local costumers toward Islamic credit cards. Management Research Review, 35(6), $512-530$.

Amin, H., Rahim, A. R. A., \& Abdul Razak, D. (2014). Consumer acceptance of Islamic home financing. International Journal of Housing Markets and Analysis, 7(3), 307-332.

Amin, H., Rahim, A. R. A., Laison, S. S., \& Magdalene, C. H. A. (2011). Determinants of customers' intention to use islamic personal financing: The case of Malaysian islamic banks. Journal of Islamic Accounting and Business Research, 2(1), 22-42. Available at: https://doi.org/10.1108/17590811111129490.

Auf, M. A. A., Salleh, S. B. M., \& Yusoff, R. Z. (2016). The relationship between word of mouth and consumer buying behavior mediating by religious orientation in Riyadh, Saudi Arabia. International Review of Management and Marketing, 6(4), 1034-1038. 
Awan, H. M., Siddiquei, A. N., \& Haider, Z. (2015). Factors affecting Halal purchase intention - evidence from Pakistan’s Halal food sector. Management Research Review, 38(6), 640-660. Available at: https://doi.org/10.1108/mrr-01-2014-0022.

Aziz, Y. A., \& Chok, N. V. (2013). The role of Halal awareness, Halal certification, and marketing components in determining Halal purchase intention among non-Muslims in Malaysia: A structural equation modeling approach. Journal of International Food \& Agribusiness Marketing, 25(1), 1-23.

Balaji, M. S. (2015). Investing in customer loyalty: The moderating role of relational characteristics. Service Business, 9(1), 17-40.

Bashir, A. M., Bayat, A., Olutuase, S. O., \& Abdul Latiff, Z. A. (2019). Factors affecting consumers' intention towards purch asing halal food in South Africa: A structural equation modelling. Journal of Food Products Marketing, 25(1), 26-48.

Bataineh, A. Q. (2015). The impact of perceived e-WOM on purchase intention: The mediating role of corporate image. International Journal of Marketing Studies, 7(1), 126-137.

Beck, T., Ongena, S., \& Şendeniz-Yüncü, İ. (2019). Keep walking? Geographical proximity, religion, and relationship banking. Journal of Corporate Finance, 55, 49-68. Available at: doi.org/10.1016/j.jcorpfin.2018.07.005

Bentler, P. M., \& Bonett, D. G. (1980). Significance tests and goodness of fit in the analysis of covariance structures. Psychological Bulletin, 88(3), 588-606.

Bhattacherjee, A. (2012). Social science research: Principles, methods, and practices (2nd ed.). Florida, USA: University of South Florida Tampa.

Buttle, F., \& Maklan, S. (2019). Customer relationship management: Concepts and technologies (3rd ed.): Routledge.

Cantrell, B. W., \& Yust, C. G. (2018). The relation between religiosity and private bank outcomes. Journal of Banking $\mathcal{E}^{2}$ Finance, 91, 86-105.

Chin, W. W., \& Newsted, P. R. (1999). Structural equation modeling analysis with small samples using partial least squares. Statistical Strategies for Small Sample Research, 1(1), 307-341.

Demo, G., Watanabe, E. A. D. M., Chauvet, D. C. V., \& Rozzett, K. (2017). Customer relationship management scale for the B2C market: A cross-cultural comparison. RAM. Mackenzie Business Review, 18(3), 42-69.

Dijkstra, T. K., \& Henseler, J. (2015). Consistent partial least squares path modeling. MIS Quarterly=Management Information Systems Quarterly, 39(2), 297-316.

Dolen, V. W. M., Dabholkar, P. A., \& De Ruyter, K. (2007). Satisfaction with online commercial group chat: The influence of perceived technology attributes, chat group characteristics, and advisor communication style. Journal of Retailing, 83(3), 339-358.

Einstein, M. (2007). Brands offaith: Marketing religion in a commercial age. New York: Routledge.

El-Bassiouny, N. (2014). The one-billion-plus marginalization: Toward a scholarly understanding of Islamic consumers. Journal of Business Research, 67(2), 42-49.

Elseidi, R. I. (2018). Determinants of halal purchasing intentions: Evidences from UK. Journal of Islamic Marketing, 9(1), 167-190.

Fishbein, M., \& Ajzen, I. (1975). Belief, attitude, intention and behavior: An introduction to theory andresearch. Reading, MA: AddisonWesley.

Fornell, C., \& Larcker, D. F. (1981). Evaluating structural equation models with unobservable variables and measurement error. Journal of Marketing Research, 18(1), 39-50.

Garbarino, E., \& Johnson, M. S. (1999). The different roles of satisfaction, trust, and commitment in customer relationships. Journal of Marketing, 63(2), 70-87.

Gauthier, F. (2016). Religion in consumer society: Brands, consumers and markets. New York: Routledge.

Gibbons, R. D., Perraillon, M. C., \& Kim, J. B. (2014). Item response theory approaches to harmonization and research synthesis. Health Services and Outcomes Research Methodology, 14(4), 213-231.

Goyette, I., Ricard, L., Bergeron, J., \& Marticotte, F. (2010). E-WOM scale: Word-of-mouth measurement scale for e-services context. Canadian Journal of Administrative Sciences, 27(1), 5-23.

Hair, J. F., Ringle, C. M., \& Sarstedt, M. (2013). Partial least squares structural equation modeling: Rigorous applications, better results and higher acceptance. Long Range Planning, 46(1-2), 1-12. 
Hair., J. F., Black, W. C., Babin, B. J., Anderson, R. E., \& Tatham, R. L. (2006). Multivariate data analysis. 6(1), 24-44.

Hanafi, A. A., \& Sallam, H. (1997). Business ethics: An islamic perspective, islamic principle of business organisation and management. Faridi, FR. (ed). Kuala Lumpur: S. Abdul Majeed \& Co.

Hanaysha, J. R., \& Pech, R. J. (2018). Brand prestige and the mediating role of word of mouth in the fast food industry. Global Business Review, 19(6), 1494-1514.

Haridan, N. M., Hassan, A. F., \& Karbhari, Y. (2018). Governance, religious assurance and Islamic banks: Do Shariah boards effectively serve? Journal of Management and Governance, 22(4), 1015-1043.

Hassan, S., Ahmad Nadzim, S. Z., \& Shiratuddin, N. (2015). Strategic use of social media for small business based on the AIDA model. Procedia-Social and Behavioral Sciences, 172, 262-269. Available at: 10.1016/j.sbspro.2015.01.363.

Henckel, T., Menzies, G. D., Moffatt, P., \& Zizzo, D. J. (2019). Three dimensions of central bank credibility and inferential expectations: The Euro zone. Journal of Macroeconomics, 60, $294-308 . \quad$ Available at: https://doi.org/10.1016/j.jmacro.2019.01.012.

Henseler, J., Dijkstra, T. K., Sarstedt, M., Ringle, C. M., Diamantopoulos, A., Straub, D. W., \& Calantone, R. J. (2014). Common beliefs and reality about PLS: Comments on Rönkkö and Evermann. Organizational Research Methods, 17(2), 182-209.

Huete-Alcocer, N. (2017). A literature review of word of mouth and electronic word of mouth: Implications for consumer behavior. Frontiers in Psychology, 8, 1256. Available at: 10.3389/fpsyg.2017.01256.

Hussain, T., Qureshi, M. H., \& Nazir, M. S. (2018). Analysis of Islamic financing and related assets: A study of Islamic banks of Pakistan. International Journal of Islamic Marketing and Branding, 3(2), 116-143.

Hussain., I., Rahman, S. U., Zaheer, A., \& Saleem, S. (2016). Integrating factors influencing consumers' halal products purchase: Application of theory of reasoned action. Journal of International Food \& Agribusiness Marketing, 28(1), 35-58.

Hutchins, B., \& Stielstra, G. (2009). Faith-based marketing: The guide to reaching 140 million Christian customers. Hoboken, New Jersey: John Wiley and Sons Inc.

IFDI. (2018). Islamic finance development report, Thomson Reuters. Retrieved from https://ceif.iba.edu.pk/pdf/ReutersIslamic-finance-development-report2018.pdf.

Iqbal, Z., \& Mirakhor, A. (2007). An introduction to islamic finance: Theory and practice. Chichester: John Wiley and Sons Ltd.

Iqbal., Q., \& Hassan, S. H. (2018). A dyadic analysis of salespersons and customers in banking sector: Humor usage, word of mouth and expectation of continuity. International Academic Journal of Business Management, 5(3), 109-120.

Islamic Bank Bulletin. (2018). Islamic banking department State Bank of Pakistan. Retrieved from https://ceif.iba.edu.pk/pdf/IslamicBankingBulletinMarch2018.pdf. [Accessed March 10, 2020].

Izberk-Bilgin, E., \& Nakata, C. C. (2016). A new look at faith-based marketing: The global halal market. Business Horizons, 59(3), 285-292.

Jaffar, M. A., \& Musa, R. (2016). Determinants of attitude and intention towards Islamic financing adoption among non-users. Procedia Economics and Finance, 37(16), 227-233.

Jeng, S.-P. (2016). The influences of airline brand credibility on consumer purchase intentions. Journal of Air Transport Management, 55, 1-8. Available at: doi.org/10.1016/j.jairtraman.2016.04.005.

Johan, Z. J., \& Putit, L. (2016). Conceptualizing the influences of knowledge and religiosity on Islamic credit card compliance. Procedia Economics and Finance, 37(16), 480-487.

Jridi, K., Chaabouni, A., Bakini, F., \& Harbaoui, M. (2018). The effect of service quality and religiosity on electronic word of mouth through satisfaction in Islamic banking in North Africa. International Journal of Islamic Marketing and Branding, $3(4), 278-298$

Kabadayi, S. (2016). Customers' dissatisfaction with banking channels and their intention to leave banks: The moderating effect of trust and trusting beliefs. Journal of Financial Services Marketing, 21(3), 194-208.

Kamarulzaman, Y., \& Madun, A. (2013). Marketing Islamic banking products: Malaysian perspective. Business Strategy Series, $14(2 / 3), 60-66$.

Keller, K. L. (2013). Strategic brand management: building, measuring, and managing brand equity (4th ed.): Pearson Education Inc. 
Khan, A., Sayyam, \& Rahman, A. (2017). Impact of Islamic motives, customer profitability and service quality on customer satisfaction from Islamic Banks. Journal of Business and Tourism, 3(1), 123-136.

Kotler, P., Keller, K. L., Ang, S. H., Tan, C. T., \& Leong, S. M. (2018). Marketing management: An Asian perspective: Pearson Education Inc.

Kudeshia, C., \& Kumar, A. (2017). Social eWOM: does it affect the brand attitude and purchase intention of brands? Management Research Review, 40(3), 310-330.

Lada, S., Tanakinjal, G. H., \& Amin, H. (2009). Predicting intention to choose halal products using theory of reasoned action. International Journal of Islamic and Middle Eastern Finance and Management, 2(1), 66-76.

Lanman, J. A., \& Buhrmester, M. D. (2017). Religious actions speak louder than words: Exposure to credibility-enhancing displays predicts theism. Religion, Brain ङ Behavior, 7(1), 3-16.

Litvin, S. W., Goldsmith, R. E., \& Pan, B. (2018). A retrospective view of electronic word-of-mouth in hospitality and tourism management. International Journal of Contemporary Hospitality Management, 30(1), 313-325.

Mahadin, B. K., \& Akroush, M. N. (2019). A study of factors affecting word of mouth (WOM) towards Islamic banking (IB) in Jordan. International Journal of Emerging Markets, 14(4), 639-667.

Martin, S. (2017). Word-of-mouth in the health care sector: A literature analysis of the current state of research and future perspectives. International Review on Public and Nonprofit Marketing, 14(1), 35-56.

Mukerjee, K. (2018). The impact of brand experience, service quality and perceived value on word of mouth of retail bank customers: Investigating the mediating effect of loyalty. Journal of Financial Services Marketing, 23(1), 12-24.

Mukhtar, A., \& Butt, M. M. (2012). Intention to choose Halal products: The role of religiosity. Journal of Islamic Marketing, 3(2), $108-120$.

Nunnally, J. C. (1978). Psychometric theory. New York: McGraw-Hill.

Pink, J. (2009). Muslim societies in the age of mass consumption. Politics, culture and identity between the local and the global. Tyne Newcastle: Cambridge Scholars.

Preda, A. (2019). How faith-based marketing can forestall the crisis of institutionalized religion. Journal for the Study of Religions and Ideologies, $18(52), 125-141$.

Rahayu, Y., Setiawan, M., Irawanto, D., \& Rahayu, M. (2020). Muslim customer perceived value on customer satisfaction and loyalty: Religiosity as a moderation. Management Science Letters, 1O(5), 1011-1016.

Rashid, A., \& Jabeen, S. (2016). Analyzing performance determinants: Conventional versus Islamic banks in Pakistan. Borsa Istanbul Review, 16(2), 92-107.

Ringle, C., Wende, S., Becker, J., \& Gmb, H. R. (2017). SmartPLS - Statistical software for structural equationmodeling [Internet]. Smartpls.com. 2017 [cited 2017 March 18]. Retrived from http://www.smartpls.com.

Salman, A., \& Nawaz, H. (2018). Islamic financial system and conventional banking: A comparison. Arab Economic and Business Journal, 13(2), 155-167.

Saqib, L., Farooq, M. A., \& Zafar, A. M. (2016). Customer perception regarding Sharī 'ah compliance of Islamic banking sector of Pakistan. Journal of Islamic Accounting and Business Research, 7(4), 282-303. Available at: https://doi.org/10.1 108/jiabr08-2013-0031.

Shafie, S., \& Othman, M. N. (2006). Halal certification: An international marketing issues and challenges. Paper presented at the Proceeding at the International IFSAM VIIIth World Congress.

Skarmeas, D., \& Shabbir, H. A. (2011). Relationship quality and giving behaviour in the UK fundraising sector: Exploring the antecedent roles of religiosity and self-construal. European Journal of Marketing, 45(5), 720-738. Available at: https://doi.org/10.1108/03090561111120000.

Souiden, N., \& Rani, M. (2015). Consumer attitudes and purchase intentions toward Islamic banks: The influence of religiosity. International Journal of Bank Marketing, 6(1), 148-163.

Suhartanto, D. (2019). Predicting behavioural intention toward Islamic bank: A multi-group analysis approach. Journal of Islamic Marketing, 10(4), 1091-1103. Available at: https://doi.org/10.1108/jima-02-2018-0041. 
Tabrani, M., Amin, M., \& Nizam, A. (2018). Trust, commitment, customer intimacy and customer loyalty in Islamic banking relationships. International Journal of Bank Marketing, 36(5), 823-848.

Tjiptoherijanto, H. U., \& Balqia, T. E. (2017). The role of religious norms, trust, importance of attributes, and information. Journal of Islamic Marketing, 8(2), 41-61.

Walsh, C. E. (2009). Inflation targeting: What have we learned? International Finance, 12(2), 195-233.

West, M. D. (1994). Validating a scale for the measurement of credibility: A covariance structure modeling approach. Journalism Quarterly, 71(1), 159-168.

Wijaya, B. S. (2015). The development of hierarchy of effects model in advertising. International Research Journal of Business Studies, 5(1), 73-85.

Wilson, J. A. (2012). The new wave of transformational Islamic marketing: Reflections and definitions. Journal of Islamic Marketing, 3(1), 5-11.

Wulandari, D., \& Subagio, A. (2015). Consumer decision making in conventional banks and islamic bank based on quality of service perception. Procedia-Social and Behavioral Sciences, 211, 471-475. Available at: doi.org/10.1016/j.sbspro.2015.11.062.

Xu, F., Guo, X., Xiao, G., \& Zhang, F. (2018). Crowdfunding or bank financing: Effects of market uncertainty and word-ofmouth communication. Retrieved from: file://C:/Users/Admin/Downloads/SSRN-id3209835.pdf. [Accesed January $13,2020]$.

Zainuldin, M. H., Lui, T. K., \& Yii, K. J. (2018). Principal-agent relationship issues in Islamic banks: A view of Islamic ethical system. International Journal of Islamic and Middle Eastern Finance and Management, 1 1(2), 297-311.

Zebal, M. A., \& Saber, H. M. (2014). Market orientation in Islamic banks-a qualitative approach. Marketing Intelligence E Planning, 32 (4), 495-527.

Zhang, L., Li, D., Cao, C., \& Huang, S. (2018). The influence of greenwashing perception on green purchasing intentions: The mediating role of green word-of-mouth and moderating role of green concern. Journal of Cleaner Production, 187, 740750. Available at: doi.org/10.1016/j.jclepro.2018.03.201.

Views and opinions expressed in this article are the views and opinions of the author(s), Asian Economic and Financial Review shall not be responsible or answerable for any loss, damage or liability etc. caused in relation to/arising out of the use of the content. 